\title{
Pengembangan Majalah Biologi Materi Keselamatan Kerja di Laboratorium Biologi untuk Siswa Kelas XI Pertanian SMK Negeri 4 Muaro Jambi
}

\author{
Reflihadi $^{1}$ \\ ${ }^{1}$ SMK Negeri 4 Muaro Jambi, Indonesia \\ Correspondance email: fyanty62@yahoo.com
}

\begin{abstract}
Abstrak. Penelitian ini bertujuan untuk memberikan solusi pada permasalahan dalam pemahaman keselamatan kerja di laboratorium biologi dengan cara mengembangkan sumber pembelajaran berupa majalah biologi materi keselamatan kerja di laboratorium biologi untuk siswa kelas XI Pertanian SMK Negeri 4 Muaro Jambi. Jenis penelitian ini adalah penelitian pengembangan dengan model ADDIE. Penelitian ini dilakukan di XI Pertanian SMK Negeri 4 Muaro Jambi. Data penelitian diambil pada 2 Januari 2019 dan diperoleh dengan cara memberikan angket kepada validator ahli media, validator ahli materi, kelompok kecil yang terdiri dari 6 orang siswa, kelompok besar yang terdiri dari 19 orang siswa, 1 orang guru bidang studi biologi dan 1 orang laboran. Hasil penelitian menunjukkan bahwa produk yang dikembangkan layak untuk digunakan sebagai sumber belajar. Hal ini ditunjukkan dari persentase proses validasi media dan materi yang dilakukan sebanyak 3 kali terus mengalami peningkatan. Persentase validasi tahap I media yaitu $60 \%$ dan materi $61,25 \%$ dalam kategori "tidak baik", kemudian mengalami peningkatan pada tahap II media yaitu $75 \%$ dan materi $66,25 \%$ dalam kategori "baik" dan akhirnya pada tahap III media yaitu $95 \%$ dan materi $88,75 \%$ dalam kategori "sangat baik". Hasil penilaian oleh 1 orang guru bidang studi biologi dengan persentase 97,5\% dalam kategori "sangat baik". Hasil penelitian oleh 1 orang laboran dengan persentase 92,5\% dalam kategori "sangat baik". Ujicoba siswa dalam kelompok kecil mendapatkan persentase 79,1\% dalam kategori "Baik" dan ujicoba siswa dalam kelompok besar mendapatkan persentase $84,8 \%$ dalam kategori "sangat baik".
\end{abstract}

Kata Kunci: Majalah Biologi, Keselamatan Kerja, Laboratorium Biologi

Abstract. This study aims to provide solutions for the problems of understanding in work safety at biology laboratory material by developing learning resources in the form of biology magazines work safety material in biology laboratory for 11th Proffesional High School On 4 Muaro Jambi. The type of this research is development research with ADDIE model. This research was conducted at kelas XI Pertanian SMK Negeri 4 Muaro Jambi. The research data was taken on January 2nd 2019 and obtained by giving a questionnaire to the media expert validator, material expert validator, a small group consisting of 6 students, a large group consisting of 19 students, a teacher of biological studies and a laboratory assistant. The results of the study show that the product is feasible to be used as learning resources. This is indicated by the results of the media validation process and the material carried out 3 times continues to increase. The percentage of stage I media validation was $60 \%$ and material validation was $61.25 \%$ in the 'not good' category, then increase in the second stage, media validation was $75 \%$ and material validation was $66.25 \%$ in the 'good' category and finally in stage III media validation was $95 \%$ and material validation was $88.75 \%$ in the 'very good' category. The results of the assessment by biology teachers with percentage of $97.5 \%$ in the 'very good' category. The results of the assessment by a laboratory assistant with percentage of $92.5 \%$ in the 'very good' category. Student trial in small groups get a percentage of $79.1 \%$ in the 'Good' category and the trials of students in large groups get a percentage of $84.8 \%$ in the 'very good' category.

Keywords: Biology Magazine, Work Safety, Biology Laboratory

\section{PENDAHULUAN}

Belajar merupakan proses mencari pengalaman yang membutuhkan proses yang kompleks dan terjadi pada diri setiap orang sepanjang hidupnya. Proses belajar tidak hanya terjadi di ruang kelas tetapi juga di mana orang tersebut berpikir dan melakukan interaksi. Sejalan dengan perkembangan pengetahuan dan teknologi, semakin banyak bentuk sumber belajar yang dapat digunakan untuk memperkaya pengetahuan. Sumber belajar adalah semua sumber yang menunjang proses pembelajaran baik berwujud orang, bahan, alat dan teknik sehingga dapat dimanfaatkan peserta didik sebagai sumber untuk kegiatan belajar dan dapat meningkatkan kualitas belajarnya. 
Cara belajar yang dimiliki oleh masing-masing peserta didik dapat berbeda satu sama lain tergantung dengan minat dan kebiasaan mereka sehari-hari. Minat sangat menentukan sukses tidaknya seseorang dalam melakukan kegiatan. Kegiatan yang dilakukan dengan senang hati akan memberikan hasil yang baik, sebab dengan adanya minat, perhatian dan usaha akan timbul untuk melakukan kegiatan tersebut. Demikian pula dengan minat membaca. Kegemaran membaca merupakan perwujudan minat seseorang. Dengan memiliki minat dan kebiasaan membaca, otak dapat bekembang, berpikir rasional dan memiliki wawasan yang lebih luas serta lebih dapat mengendalikan diri. Semakin tinggi minat baca pada diri seseorang semakin tinggi pula hasil belajar yang diterimanya, sehingga diharapkan dapat mencapai tujuan belajar optimal.

Namun, permasalahan akan kurangnya minat membaca pada peserta didik masih banyak ditemukan. Beberapa penyebabnya adalah masih banyaknya penggunaan metode ceramah pada proses pembelajaran sehingga peserta didik terbiasa untuk mendengar dan belajar secara pasif. Waktu pembelajaran yang lama dan panjang memberi kesan kepada peserta didik bahwa jumlah pengetahuan yang mereka terima sudah cukup banyak tanpa harus mencari tambahan pengetahuan lagi. Selain itu, sumber belajar yang dapat digunakan oleh peserta didik baik di dalam maupun di luar kelas masih belum banyak tersedia, sehingga sebagian besar sumber informasi dan pengetahuan yang dapat dimanfaatkan hanya berupa buku cetak dan lembar kerja peserta didik (LKPD) yang terkesan berat dan monoton.

Salah satu cara untuk menumbuhkan minat membaca pada peserta didik adalah dengan memadukan antara perkembangan teknologi dengan pendidikan yang kemudian menghasilkan suatu produk berupa sumber belajar yang lebih fleksibel, menarik dan mudah dimengerti oleh peserta didik. Jika buku teks dan LKPD terasa berat dan monoton maka sumber belajar dapat dibuat lebih menarik salah satunya dalam bentuk majalah. Menurut penelitian yang dilakukan oleh Mustikarini (2016:98) majalah terbukti dapat menjadi sumber belajar, mampu meningkatkan pencapaian nilai spiritual siswa yang dapat dilihat dari skor serta mampu menumbuhkan motivasi belajar siswa. Selain itu penelitian yang dilakukan oleh Dewi dan Agus (2014:155) menunjukkan bahwa majalah Green layak digunakan oleh peserta didik sebagai sumber belajar dengan rata-rata hasil penilaian dalam kategori baik.

Walaupun dalam pembuatan majalah membutuhkan waktu yang cukup lama dan tingkat imajinasi yang tinggi, namun hal itu dapat ditutupi dengan beberapa kelebihannya antara lain; lebih fleksibel, karena majalah dapat dibawa dan digunakan di mana saja tanpa harus menggunakan media elektronik tambahan seperti komputer, laptop, handphone, ataupun internet. Lebih menarik dari bentuk desain dan kualitas kertas yang digunakan. Terdapat gambar dan foto sehingga proses pembelajaran terkesan lebih nyata. Serta bahasa yang lebih ringan dan mudah dimengerti oleh peserta didik. Dengan menggunakan majalah sebagai sumber belajar siswa dapat memperoleh informasi dengan lebih menyenangkan.

Berdasarkan hasil observasi yang dilakukan pada peserta didik kelas XI Pertanian SMK Negeri 4 Muaro Jambi pada tanggal 12 Oktober 2018 terdapat materi yang belum maksimal disampaikan oleh guru dalam proses pembelajaran yaitu pada materi kerja ilmiah dan keselamatan kerja. Penyebab utamanya adalah karena kurangnya waktu yang tersedia untuk menyampaikan materi tersebut dan belum tersedianya sumber belajar tambahan selain buku teks dan LKPD yang pembahasannya masih bersifat dasar sehingga peserta didik masih banyak yang belum menguasai materi kerja ilmiah dan keselamatan kerja. Hal ini merupakan suatu permasalah yang tidak dapat diabaikan karena pengetahuan tentang kerja ilmiah dan keselamatan kerja adalah suatu pengetahuan dasar yang harus dikuasai oleh peserta didik untuk dapat bekerja secara benar dan aman khususnya di dalam laboratorium.

Berdasarkan permasalahan tersebut maka diperlukan suatu sumber belajar yang fleksibel dan menarik berupa pengembangan majalah yang berisikan materi kerja ilmiah dan keselamatan kerja. Di samping dapat memenuhi kebutuhan informasi yang dibutuhkan, minat membaca pada peserta didik juga dapat ditimbulkan karena sumber bacaan disajikan dengan lebih menyenangkan.

Hal ini mendorong penulis untuk membuat suatu penelitian pengembangan majalah dengan materi kerja ilmiah dan keselamatan kerja yang mana materi ini masih jarang disentuh untuk dijadikan bahan pengembangan sumber belajar. Berdasarkan hal tersebut, menurut peneliti perlu dilakukan penelitian yang berjudul "Pengembangan Majalah Biologi Materi Keselamatan Kerja di Laboratorium Biologi untuk Siswa Kelas XI Pertanian SMK Negeri 4 Muaro Jambi"

\section{METODE PENELITIAN}

Metode yang digunakan dalam Model pengembangan yang digunakan peneliti adalah model pengembangan ADDIE. Model ADDIE termasuk ke dalam model prosedural di mana menurut Setyosari (2010:284) model prosedural adalah model deskriptif yang menggambarkan alur atau langkah-langkah prosedural yang harus diikuti untuk menghasilkan suatu produk tertentu. Adapun langkah-langkah pengembangan dalam model ADDIE ditunjukkan pada gambar berikut : 


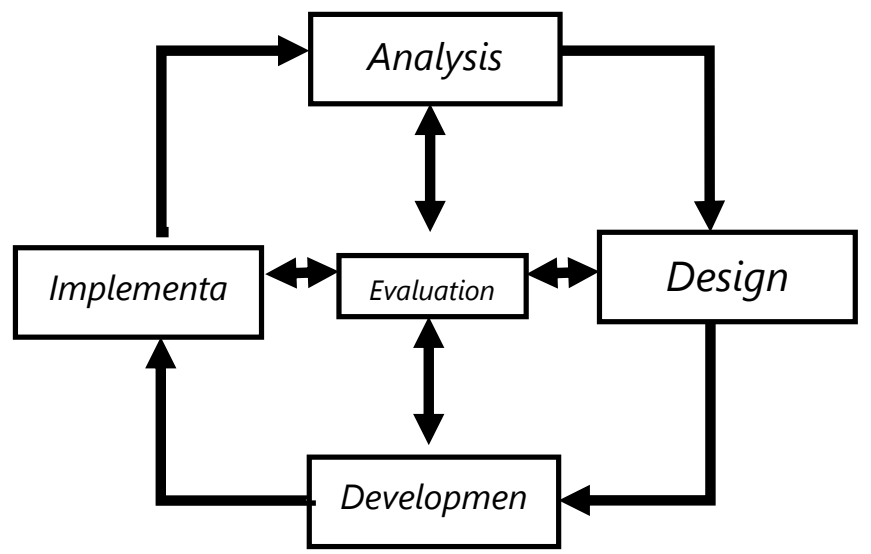

Gambar 1 Konsep pengembangan model ADDIE (Tegeh, 2014:41)

\section{a. Analisis (Analysis)}

Tahap analisis merupakan suatu langkah untuk mengetahui analisis kebutuhan dari karakteristik siswa dalam pembelajaran, kemudian media apa yang digunakan di dalam kelas selama proses pembelajaran berlangsung dan materi pembelajaran apa yang dianggap siswa masih abstrak.

\section{b. Desain (Design)}

Berdasarkan hasil analisis kebutuhan, tahap selanjutnya adalah tahap desain atau perancangan produk. Tahap awal dimulai dengan membuat jadwal pembuatan produk, penentuan tim validasi, membuat spesifikasi desain majalah, pembuatan langkah-langkah pengembangan majalah dan membuat Storyboard.

\section{c. Pengembangan (Develop)}

Ditahap ini rancangan majalah dituangkan ke dalam aplikasi adobe inDesign untuk mendesign halaman satu persatu, kemudian dibantu dengan penggunaan aplikasi Photoshop CS6 untuk mengedit gambar-gambar yang diperlukan, setelah digabungkan baru masuk ke tahap pencetakan. Pada saat majalah telah dicetak dilanjutkan dengan validasi dari tim validator desain dan materi. Validasi produk ditujukan untuk menemukan kesesuaian serta ketidak sesuaian yang ada pada produk yang dikembangkan, ketidak sesuaian ini selanjutnya akan direvisi kembali hingga produk valid dan siap diujicobakan.

\section{d. Implementasi (Implemention)}

Implementasi merupakan tahap ujicoba yang dilaksanakan setelah proses pengembangan selesai. Pada tahapan ini produk yang telah dinilai dan dinyatakan layak oleh validator diujicobakan kepada siswa XI Pertanian SMK Negeri 4 Muaro Jambi, satu orang guru mata pelajaran biologi dan satu orang laboran pada XI Pertanian SMK Negeri 4 Muaro Jambi. Selama proses ujicoba, objek diberi angket penilaian terhadap produk untuk diperoleh respon dan data sebagai acuan dan pedoman revisi untuk memperbaiki produk.

\section{e. Evaluasi (Evaluate)}

Tahap evaluasi dilakukan melalui validasi produk dari ahli media dan materi, serta hasil ujicoba pada siswa, guru dan laboran. Hasil dari evaluasi ini akan dijadikan perbandingan untuk memperbaiki produk yang dikembangkan dan melihat apakah produk yang dikembangkan sudah layak dan dapat digunakan sebagai sumber belajar mandiri bagi peserta didik pada materi kerja ilmiah dan keselamatan kerja.

\section{Subjek Ujicoba}

Subjek ujicoba produk majalah biologi materi keselamatan kerja di laboratorium biologi ini adalah siswa Kelas XI Pertanian SMK Negeri 4 Muaro Jambi yang terbagi menjadi kelompok kecil dan kelompok besar. Kelompok kecil berjumlah 6 orang siswa dan kelompok besar terdiri dari 19 orang siswa. Penentuan jumlah kelompok ini berdasarkan pernyataan Setyosari (2016:288-289) uji coba kelompok kecil terdiri atas 5-8 subjek sedangkan untuk kelompok besar terdiri dari 15-30 subjek atau lebih.

\section{Jenis Data dan Sumber Data}

Jenis data pada penelitian pengembangan ini ada dua yaitu data kualitatif dan data kuantitatif. Data kualitatif diperoleh dari validator ahli materi dan media berupa saran dan masukan terhadap produk yang dikembangkan. Data kuantitatif akan diperoleh dari hasil jumlah skor angket penilaian validator ahli baik ahli materi dan ahli media serta 
guru, laboran dan peserta didik sebagai responden yang memberikan persepsi dan penilaian terhadap produk majalah biologi materi keselamatan kerja di laboratorium biologi yang dikembangkan.

\section{Instrumen Pengumpulan Data}

Dalam penelitian pengembangan ini, instrumen pengumpulan data dilakukan dengan menggunakan metode kuesioner (angket). Menurut Sanjaya (2013:255) angket adalah instrumen penelitian berupa daftar pertanyaan secara tertulis yang harus dijawab atau diisi oleh responden sesuai dengan petunjuk pengisiannya. Angket yang digunakan pada peneltian ini merupakan angket tertutup dengan menggunakan 4 kategori penilaian dari rating scale. Menurut Sanjaya (2013:276) Skala penilaian (Rating Scale) adalah instrumen observasi yang berisi tentang segala aspek yang diobservasi yang dikategorikan dalam bentuk skala yang dijadikan pedoman oleh observer untuk menentukan dalam rentangan beberapa aspek yang diobservasi itu kira-kira berada

\section{Teknik Analisis Data}

Teknik analisis data pada penilaian ini didapatkan dari hasil perhitungan jumlah skor yang diperoleh dari penilaian angket validator, guru, laboran dan siswa. Dengan menggunakan skor, maka dapat diperoleh deskripsi tentang seberapa nilai atau harga suatu variabel untuk masing-masing unit analisis dalam penelitian. Skor maksimal skala sikap bagi suatu unit analisis adalah jumlah item dalam skala skiap dikalikan dengan skor tertinggi sedangkan untuk skor minimalnya adalah jumlah item dalam skala sikap dikalikan skor terendah.

Penentuan skala validasi serta respon guru dan siswa menggunakan rating scale sebagai berikut :

Tabel 1 Ketentuan pemberian skor

\begin{tabular}{ccc}
\hline No & Kriteria Respon & Skala angka \\
\hline 1 & Sangat baik & 4 \\
\hline 2 & Baik & 3 \\
\hline 3 & Tidak baik & 2 \\
\hline 4 & Sangat tidak baik & 1 \\
\hline Sumber: modifikasi Riduwan $(2015: 94)$
\end{tabular}

Angket yang diperoleh kemudian dipresentasikan dengan menggunakan rumus sebagai berikut:

Skor maksimum = Skor penilaian maksimum $\mathrm{x}$ jumlah item deskriptor $\mathrm{x}$ jumlah responden

Skor minimum $=$ Skor penilaian minimum $\mathrm{x}$ jumlah item deskriptor $\mathrm{x}$ jumlah responden

Rental Interval = Skor maksimum -

skor minimum

Kategori Penilaian

1. Penilaian Angket Oleh Validasi Media dan Materi

Jumlah soal angket validasi media dan validasi materi adalah sebanyak 20 item. Sehingga secara teoritik akan diperoleh skor sebagai berikut:

Skor maksimum $\quad=4 \times 20 \times 1=80$

Skor minimum $=1 \times 20 \times 1=20$

Kategori Kriteria $=4$

Rentang $\quad==($ Skor maksimum - skor minimum $) / 4=(80-20) / 4=15$

Interpresentasi skor untuk validasi media dan materi dapat dilihat pada Tabel 2 berikut:

Tabel 2 Kategori penilaian validasi media dan materi

\begin{tabular}{cccc}
\hline No. & $\begin{array}{c}\text { Skala } \\
\text { Nilai }\end{array}$ & Skor & $\begin{array}{c}\text { Tingkat } \\
\text { Kategori }\end{array}$ \\
\hline 1 & 4 & $65-80$ & Sangat baik \\
\hline 2 & 3 & $\begin{array}{c}50- \\
64,99\end{array}$ & Baik \\
\hline 3 & 2 & $\begin{array}{c}35- \\
49,99\end{array}$ & Tidak Baik \\
\hline 4 & 1 & $20-$ & Sangat tidak \\
\hline
\end{tabular}




$\frac{34,99}{\text { baik }}$

Menurut Riduwan (2015:95), data yang diperoleh dari penelitian angket ujicoba kemudian ditabulasi dan dianalisis dengan menghitung persentase skor menggunakan rumus sebagai berikut:

Persentase tanggapan $=$

Jumlah skor yang diperoleh $\mathrm{x} \quad 100 \%$

Jumlah skor maksimum

2. Penilaian Angket Oleh Guru dan Laboran

Angket persepsi guru dan laboran terdiri dari 10 item pertanyaan. Sehingga secara teoritik akan diperoleh skor sebagai berikut:

Skor maksimum $\quad=4 \times 10 \times 1=40$

Skor minimum $=1 \times 10 \times 1=10$

Kategori Kriteria $\quad=4$

Rentang $\quad=($ Skor maksimum - skor minimum $)=(40-10) / 4=7,5$

Interpresentasi skor untuk validasi media dan materi dapat dilihat pada Tabel 3 berikut:

Tabel 3 Kategori penilaian persepsi guru dan laboran

\begin{tabular}{cccc}
\hline No. & $\begin{array}{c}\text { Skala } \\
\text { Nilai }\end{array}$ & Skor & $\begin{array}{c}\text { Tingkat } \\
\text { Kategori }\end{array}$ \\
\hline 1 & 4 & $32,5-40$ & Sangat baik \\
\hline 2 & 3 & $25-32,49$ & Baik \\
\hline 3 & 2 & $17,5-24,99$ & Tidak baik \\
\hline 4 & 1 & $10-17,49$ & $\begin{array}{c}\text { Sangat tidak } \\
\text { baik }\end{array}$ \\
\hline \multicolumn{4}{l}{ Sumber : modifikasi Riduwan $(2015: 95)$}
\end{tabular}

Menurut Riduwan (2015:95), data yang diperoleh dari penelitian angket ujicoba kemudian ditabulasi dan dianalisis dengan menghitung persentase skor menggunakan rumus sebagai berikut:

Persentase tanggapan =

Jumlah skor yang diperoleh $\mathrm{x}$ 100\%

Jumlah skor maksimum

3. Penilaian Angket Oleh Siswa

Angket persepsi pada ujicoba kelompok kecil berjumlah 6 responden dan kelompok besar berjumlah 19 responden yang terdiri dari 10 item pertanyaan.

a. Penilaian terhadap kelompok kecil

Untuk ujicoba kelompok kecil secara teoritik akan diperoleh skor sebagai berikut:

Skor maksimum $\quad=4 \times 10 \times 6=240$

Skor minimum $=1 \times 10 \times 6=60$

Kategori Kriteria $=4$

Rentang $\quad==($ Skor maksimum - skor minimum $) / 4=(240-60)=45$

Interpresentasi skor untuk validasi media dan materi dapat dilihat pada Tabel 4 berikut:

Tabel 4 Kategori penilaian persepsi siswa kelompok kecil

\begin{tabular}{cccc}
\hline No. & $\begin{array}{c}\text { Skala } \\
\text { Nilai }\end{array}$ & Skor & $\begin{array}{c}\text { Tingkat } \\
\text { Kategori }\end{array}$ \\
\hline 1 & 4 & $195-240$ & Sangat baik \\
\hline 2 & 3 & $150-$ & Baik \\
\hline
\end{tabular}




\begin{tabular}{cccc}
\hline \multicolumn{4}{c}{194,99} \\
\hline 3 & 2 & $105-$ & Tidak baik \\
& & 149,99 & \\
\hline 4 & 1 & $60-104,99$ & Sangat tidak baik \\
\hline
\end{tabular}

b. Penilaian terhadap kelompok besar

Untuk perhitungan skor pada kelompok besar secara teoritik akan diperoleh skor sebagai berikut :

Skor maksimum $\quad=4 \times 10 \times 19=760$

Skor minimum $=1 \times 10 \times 19=190$

Kategori Kriteria $\quad=4$

Rentang $\quad=($ Skor maksimum- skor minimum $) / 4=(760-190) / 4=142,5$

Interpresentasi skor untuk validasi media dan materi dapat dilihat pada Tabel 5 berikut:

Tabel 5 Kategori penilaian persepsi siswa kelompok besar

\begin{tabular}{cccc}
\hline No. & $\begin{array}{c}\text { Skala } \\
\text { Nilai }\end{array}$ & Skor & $\begin{array}{c}\text { Tingkat } \\
\text { Kategori }\end{array}$ \\
\hline 1 & 4 & $617,5-760$ & Sangat baik \\
\hline 2 & 3 & $475-617,49$ & Baik \\
\hline 3 & 2 & $\begin{array}{c}332,5- \\
474,99\end{array}$ & Tidak baik \\
\hline 4 & 1 & $190-332,49$ & $\begin{array}{c}\text { Sangat tidak } \\
\text { baik }\end{array}$ \\
\hline
\end{tabular}

Sumber: modifikasi Riduwan (2015: 95)

Menurut Riduwan (2015:95), data yang diperoleh dari penelitian angket ujicoba kemudian ditabulasi dan dianalisis dengan menghitung persentase skor menggunakan rumus sebagai berikut:

Persentase tanggapan =

Jumlah skor yang diperoleh $\mathrm{x} \quad 100 \%$

Jumlah skor maksimum

\section{HASIL DAN PEMBAHASAN}

Analisis Data Ahli Media

Produk yang telah dikembangkan berupa majalah biologi materi keselamatan kerja di laboratorium biologi kemudian divalidasi oleh ahli media. Validasi media dilakukan tiga kali dan hasil validasi tersebut terdapat saran dan komentar sebagai acuan untuk memperbaiki produk yang dikembangkan. Produk yang dikembangkan dapat diujicobakan jika ahli media menyatakan "produk layak diujicobakan tanpa revisi".

Hasil validasi media tahap I sebesar 48 dengan hasil persentase yaitu $60 \%$ termasuk kategori "Tidak baik". Hal ini dikarenakan masih terdapat cukup banyak item yang belum sesuai seperti pada indikator konsistensi, indikator format, indikator organisasi, indikator daya tarik dan indikator kesesuaian huruf, saran yang diberikan berkaitan dengan penulisan judul yang disesuaikan dengan isi, ukuran huruf yang diperbesar, warna huruf agar lebih kontras dan jenis huruf yang lebih bervariasi. Kesimpulan hasil validasi media tahap pertama belum layak dan masih harus diperbaiki lagi.

Hasil validasi pada tahap II, diketahui skor penilaian sebesar 60 dengan hasil persentase yaitu $75 \%$ termasuk kategori "Baik". Setelah dilakukan perbaikan dan proses validasi tahap III maka diperoleh skor yaitu sebesar 76 dengan hasil persentase yaitu 95\% termasuk kategori "Sangat Baik". Setelah perbaikan dilakukan sesuai saran dan komentar yang diberikan, akhirnya validator media memberikan kesimpulan hasil validasi media tahap ketiga adalah layak digunakan tanpa revisi. Berdasarkan hasil validasi yang dilakukan sebanyak tiga kali tercantum pada Gambar 2 berikut: 


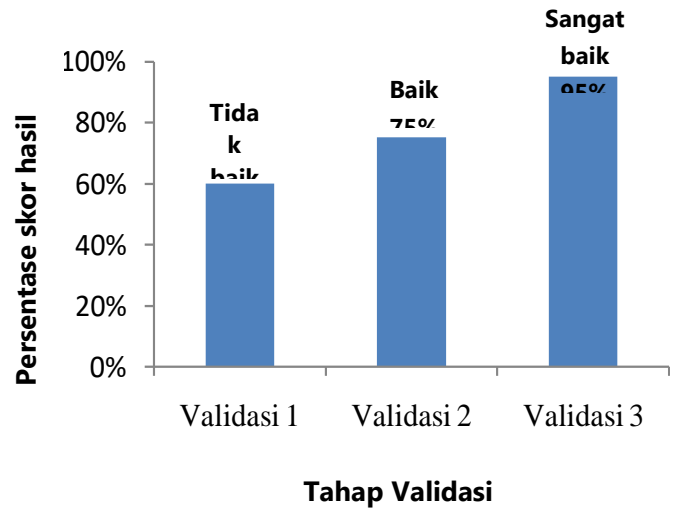

\section{Analisis Data Ahli Materi}

\section{Gambar 2 Grafik hasil validasi oleh ahli media}

Produk yang telah dikembangkan berupa majalah biologi materi keselamatan kerja di laboratorium biologi kemudian divalidasi oleh ahli materi. Validasi materi dilakukan tiga kali kemudian dari hasil validasi tersebut terdapat saran dan komentar sebagai acuan untuk memperbaiki produk yang dikembangkan. Produk yang dikembangkan dapat diujicobakan jika ahli materi menyatakan "produk layak diujicobakan tanpa revisi".

Berdasarkan hasil validasi materi tahap I, diketahui skor yang diperoleh dari 20 item penilaian sebesar 49 dengan persentase $61,25 \%$ termasuk kategori "Tidak baik". Hal ini dikarenakan masih banyak aspek penilaian yang masih perlu diperbaiki seperti pada indikator konstruksi isi, indikator kemenarikan, indikator kelengkapan, dan indikator kegrafisan. Hasil validasi tahap II, diketahui skor yang diperoleh dari 20 item penilaian sebesar 53 dengan persentase $66,25 \%$ termasuk kategori "Baik". Setelah dilakukan perbaikan dan proses validasi tahap III maka diperoleh skor yaitu sebesar 71 dengan hasil persentase 88,75\% termasuk kategori "Sangat baik". Pada tahap ketiga tidak dilakukan revisi karena kesimpulan validasi pada tahap ini produk layak digunakan tanpa revisi.

Berdasarkan hasil validasi yang dilakukan sebanyak tiga kali tercantum pada Gambar 3 berikut:

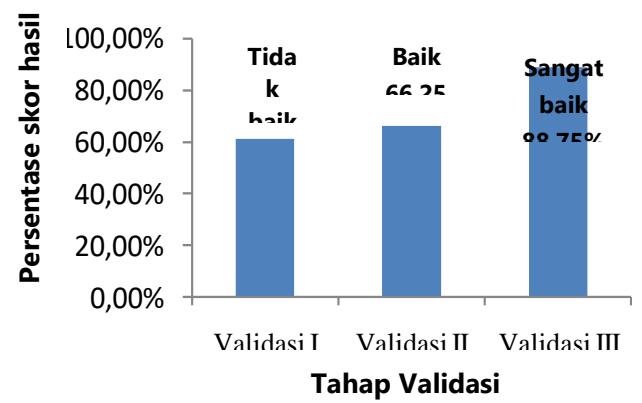

\section{Gambar 3 Grafik hasil validasi oleh ahli materi}

\section{Analisis Data Persepsi Guru}

Hasil ujicoba persepsi guru diketahui skor produk dari 10 item penilaian sebesar 39 dengan persentase sebesar 97,5\% termasuk kategori "sangat baik". Hasil persentase pada indikator kualitas isi yaitu 95,83\% sedangkan untuk persentase pada indikator manfaat, tampilan dan teknis penggunaan yaitu $100 \%$ yang mana semua persentase masuk dalam kategori "sangat baik".). Berdasarkan hasil ujicoba persepsi guru tercantum pada Gambar 4 berikut:

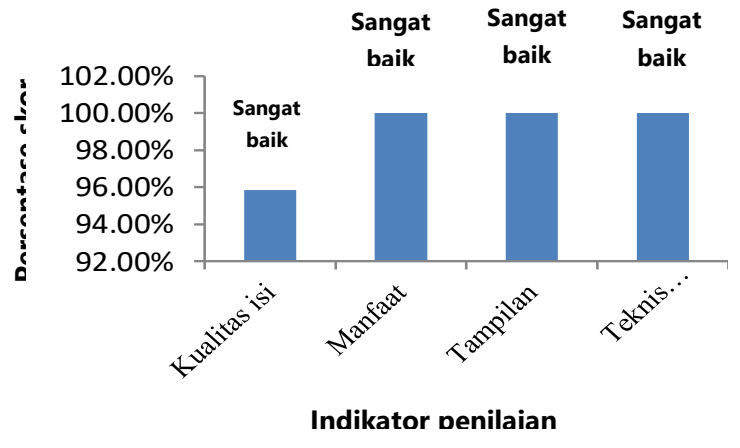

Gambar 4 Grafik hasil ujicoba persepsi guru per indicator. 


\section{Analisis Data Persepsi Laboran}

Berdasarkan hasil ujicoba persepsi laboran diketahui skor dari 10 item penilaian sebesar 37 dengan persentase sebesar 92,5\% termasuk kategori "sangat baik". Hasil persentase pada indikator kualitas isi yaitu 91,67\%, indikator tampilan $87,5 \%$, sedangkan untuk persentase pada indikator manfaat dan teknis penggunaan yaitu $100 \%$ yang mana semua persentase masuk dalam kategori "sangat baik". Berdasarkan hasil ujicoba persepsi guru tercantum pada Gambar 5 berikut:

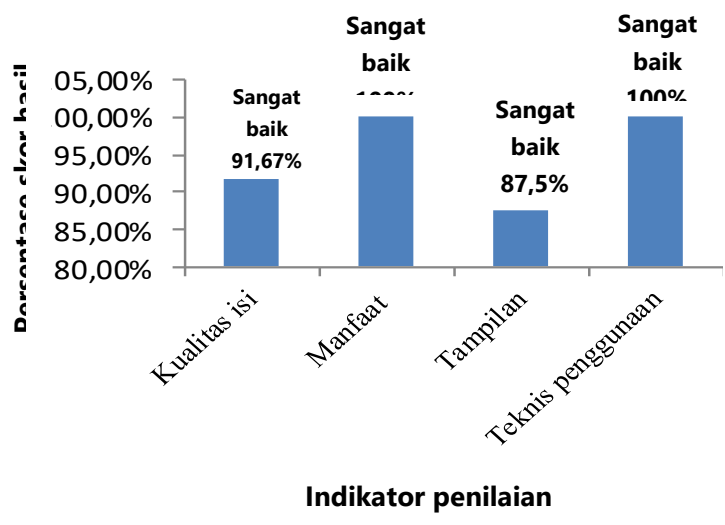

\section{Gambar 5 Grafik hasil ujicoba persepsi laboran per indicator.}

\section{Analisis Data Kelompok Kecil}

Hasil ujicoba kelompok kecil terhadap produk yang dikembangkan, diperoleh skor keseluruhan 190 dengan kategori "baik". Skor yang diperoleh terdiri dari empat indikator yaitu skor indikator tampilan 53 dengan persentase 73,6\% termasuk dalam kategori "baik", skor indikator kejelasan materi 78 dengan persentase 81,25\% termasuk kategori "sangat baik", skor indikator manfaat 39 dengan persentase $81,25 \%$ dengan kategori "sangat baik" dan skor indikator teknis penggunaan 20 dengan persentase 83,33\% termasuk kategori "sangat baik". Hasil ujicoba kelompok kecil tercantum pada Gambar 6 berikut:

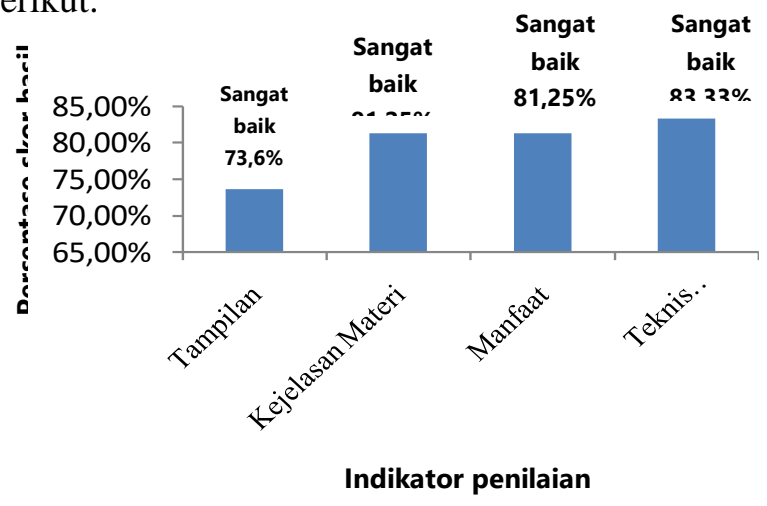

\section{Analisis Data Kelompok Besar}

Gambar 6 Grafik hasil ujicoba kelompok kecil per indicator

Hasil ujicoba kelompok besar terhadap produk yang dikembangkan, diperoleh skor keseluruhan 645 dengan kategori "Sangat baik". Skor yang diperoleh terdiri dari empat indikator, yaitu skor indikator tampilan 181 dengan persentase 79,38\% termasuk dalam kategori "sangat baik", skor indikator kejelasan materi 264 dengan persentase $86,84 \%$ termasuk kategori "sangat baik", skor indikator manfaat 136 dengan persentase $89,47 \%$ dengan kategori "sangat baik" dan skor indikator teknis penggunaan 64 dengan persentase 84,21\% termasuk kategori "sangat baik". Hasil ujicoba kelompok besar tercantum pada Gambar 7 berikut: 


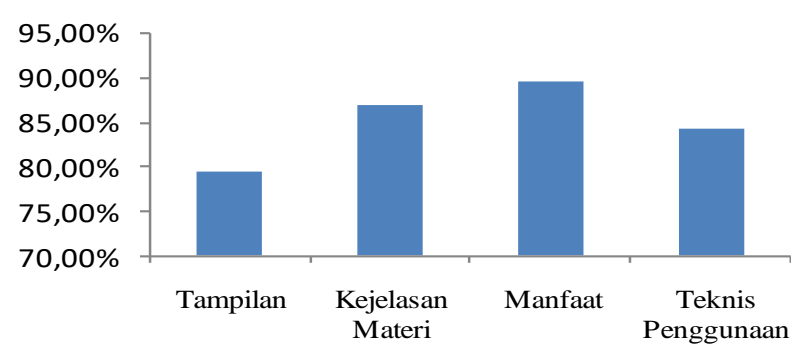

Gambar 7 Grafik hasil ujicoba kelompok besar per indikator

\section{SIMPULAN}

Adapun kesimpulan dari penelitian ini yaitu 1) Majalah bioloi (BIOMAGZ) materi keselamatan kerja di laboratorium biologi untuk siswa kelas XI Pertanian SMK Negeri 4 Muaro Jambi dinyatakan layak digunakan sebagai sumber belajar siswa berdasarkan hasil validasi ahli media dilakukan sebanyak tiga kali dengan nilai akhir 95\% termasuk kategori "sangat baik" dan validasi ahli materi juga dilakukan sebanyak tiga kali dengan nilai akhir $88,75 \%$ termasuk kategori "sangat baik". 2) Respon guru terhadap majalah sebesar 97,5\% termasuk kategori "sangat baik". 4) Respon laboran terhadap majalah sebesar 92,5\% termasuk kategori "sangat baik". 3) Persentase rata-rata ujicoba kelompok kecil terhadap majalah sebesar 79,1\% dengan kategori "baik" dan persentase rata-rata ujicoba kelompok besar terhadap majalah sebesar 84,8\% dengan kategori "sangat baik".

Saran yang dapat diberikan dari penelitian ini adalah 1) Penelitian ini dapat dijadikan sebagai bahan masukan dan acuan dalam mengembangkan produk media yang relevan. 2) Majalah biologi materi keselamatan kerja di laboratorium biologi untuk siswa kelas XI Pertanian SMK Negeri 4 Muaro Jambi dapat dikembangkan lebih lanjut dengan materi yang lain. 3) Majalah biologi materi keselamatan kerja di laboratorium biologi untuk siswa kelas XI Pertanian SMK Negeri Muaro Jambi Kota Jambi dapat digunakan sebagai sumber belajar bagi siswa.

\section{DAFTAR PUSTAKA}

Dewi, N.A. dan Agus. W.D.D.W. 2014. Pengembangan majalah Green sebagai media pembelajaran Biologi pada materi sistem reproduksi manusia untuk siswa kelas XI IPA SMA. Jupemasi-PBIO 1(1): 155-157.

Mustikarini, P. 2016. Pengembangan majalah fisika sebagai alternatif sumber belajar mandiri berkarakter islami melalui materi fluida dinamis untuk menumbuhkan sikap spiritual dan motivasi belajar siswa kelas XI SMA Negeri 1 Bantul. Jurnal Pendidikan Fisika 5(2): 98-105.

Riduwan. 2015. Belajar Mudah Penelitian Untuk Guru-Karyaan dan Peneliti Pemula. Bandung: ALFABETA.

Sanjaya, W. 2013. Penelitian Pendidikan Jenis, Metode dan prosedur. Jakarta : Prenada Media Group.

Setyosari, P. 2010. Metode Penelitian Pendidikan dan Pengembangan. Jakarta: Kencana Prenada Media Group.

Sugiyono. 2015. Metoode Penelitian Pendidikan Pendekatan Kuantitatif, Kualitatif, dan R\&D. Bandung : Alfabeta.

Tegeh, M., I. Nyoman, J. dan Ketut, P. 2014. Model Penelitian Pengembangan. Yogyakarta : Graha Ilmu. 